\title{
Influência do Tipo de Coleta (Comum ou Seletiva) na Reciclagem de Filmes de Poliolefinas Pós-consumo
}

\author{
Sandro D. Mancini, Alex R. Nogueira, Dennis A. Kagohara, Jonas A. S. Schwartzman, Tânia de Mattos, André H. Rosa \\ Engenharia Ambiental, UNESP
}

\begin{abstract}
Resumo: Filmes de polipropileno (PP) e de polietilenos de alta (HDPE) e baixa densidades (LDPE) foram estudados avaliando-se a presença de impurezas e o efluente da lavagem de seus resíduos provenientes tanto de coleta comum (resíduos misturados) quanto seletiva (resíduos separados). Os resultados apontam que os filmes estavam impregnados com, no mínimo, 30\% de impurezas quando provenientes de coleta comum e com, no máximo, 10\% quando de coleta seletiva. Esses resultados, associados aos da turbidez do efluente de lavagem, indicam que dos filmes de coleta seletiva, preferidos pelos recicladores, se obtém pelo menos $20 \%$ mais material e tem-se uma lavagem mais fácil, por envolver praticamente só a retirada de sólidos, ao contrário da coleta comum, associada a resíduos úmidos impregnados. Os efluentes foram também avaliados segundo sólidos totais, sólidos sedimentáveis e o teor de nove metais. Os resultados indicaram que os dois tipos de coleta geram efluentes semelhantes e que no máximo duas etapas devem ser suficientes para seus tratamentos: decantação e diluição do efluente no corpo d'água receptor.
\end{abstract}

Palavras-chave: Reciclagem, filmes plásticos, coleta seletiva, polietileno, polipropileno, tratamento de efluentes industriais.

\section{Influence from the Type of Waste Collection (Mixed or Segregated) on Recycling Post-consumer Polyolefins Films}

Abstract: Polypropylene (PP), high density polyethylene (HDPE) and low density polyethylene (LDPE) films were studied according to the way their wastes are collected (segregated from or mixed with other residues) by evaluating the amount of impurities and the washing wastewater. It was found that the films from mixed collection presented at minimum $30 \%$ of impurities, while the films from segregated (or curbside) collection presented at maximum $10 \%$ of impurities. The amount of impurities and the wastewater turbidity indicated that $20 \%$ more material can be obtained from the films of segregated colletion, preferred by recyclers, in addition to having a simpler washing process because it only involves solids removal, unlike mixed collection which is associated with the impregnation of wet wastes. The effluents were also evaluated according to the total amount of solids, sediments and concentration of nine metals. The results showed that both types of collection generated similar wastewaters and their treatment requires two steps at the most: sedimentation and effluent dilution in the water body.

Keywords: Recycling, plastic films, curbside collection, polypropylene, polyethylene, industrial wastewater treatment.

\section{Introdução}

Pela baixa densidade e elevada área superficial, os filmes plásticos descartados podem possuir uma grande quantidade de impurezas em relação ao seu peso. Estas impurezas podem ser provenientes do contato do plástico com o produto embalado durante a vida útil do filme e/ou com outros produtos descartados. Por melhor que seja a separação dos filmes em relação a outros resíduos, em muitos casos é imprescindível a lavagem para a retirada das impurezas ainda presentes na superfície dos filmes. Caso contrário, essas impurezas podem ser transferidas aos equipamentos de processamento, dificultando ou mesmo impedindo a obtenção de produtos de qualidade ${ }^{[1-4]}$.

Dessa maneira, um sistema de lavagem eficiente transfere impurezas do plástico para a água. Esta transferência significa custos adicionais intrínsecos à etapa bem como os relacionados ao tratamento para tornar o efluente apto a novo consumo industrial ou ao despejo na rede coletora de esgoto. Isto porque a lavagem pode representar significativo impacto ambiental se seu efluente for descartado, como de fato é feito clandestinamente por algumas recicladoras, diretamente em rios, lagos ou lagoas ou indiretamente em galerias de água pluviais, ações que tem manchado a reputação "ecológica" da reciclagem de plásticos.

A grosso modo, há duas formas de se obter filmes plásticos para a reciclagem. Uma forma é a coleta seletiva, que sabidamente auxilia a reciclagem por facilitar a captação de matéria-prima em quantidade e qualidade, e que pode ser realizada pela população, indústrias, catadores, sucateiros, cooperativas etc. Outra forma é a coleta comum ou misturada, realidade na grande maioria dos municípios brasileiros, e que tende a facilitar a impregnação de impurezas em todos os materiais de interesse para a reciclagem.

Autor para correspondência: Sandro D. Mancini, Engenharia Ambiental, UNESP-Sorocaba, Avenida 3 de Março, 511, Alto da Boa Vista, CEP: 18087-180, Sorocaba, SP, Brasil. E-mail: mancini@sorocaba.unesp.br 
Independente da forma de coleta, nos resíduos sólidos urbanos há uma grande quantidade de plásticos descartados, ou seja, matéria-prima para a reciclagem. Segundo um estudo realizado no Aterro Sanitário de São Carlos-SP em 2005 (população de 214.000 habitantes), 10,47\% dos de resíduos sólidos domésticos eram plásticos, sendo 7,63\% filmes e 2,84\% rígidos ${ }^{[5]}$. De acordo com caracterização realizada com os resíduos domésticos da cidade de Indaiatuba-SP em 2004 e 2005 (população de 175 mil habitantes), em termos de peso, $10,8 \%$ do que a cidade descarta eram plásticos, sendo $5,1 \%$ rígidos e $5,7 \%$ filmes. Dos filmes plásticos descartados no Aterro de Indaiatuba, 2,4\% eram polietileno de alta densidade (HDPE ou PEAD), 2,3\% polietileno de baixa densidade (LDPE ou PEBD) e 0,9\% polipropileno (PP), as principais poliolefinas em termos de consumo e descarte. A reciclagem destes materiais certamente representaria uma economia de recursos naturais e de espaço em aterros sanitários: segundo estimativas em termos de volume, 19,6\% dos resíduos domésticos de Indaiatuba eram filmes de HDPE, LDPE e PP ${ }^{[6]}$.

Este trabalho teve por objetivo avaliar as etapas iniciais da reciclagem normalmente realizada com filmes plásticos (separação e lavagem) provenientes de coleta seletiva e de coleta comum. Para isto, foi feita a quantificação das impurezas - retiradas pela lavagem - presentes nos três tipos de filmes mais comumente descartados, HDPE, LDPE e PP. Também, características físico-químicas da água de lavagem e possibilidades de tratamento foram avaliadas a partir dos resultados de ensaios de teor de sólidos, turbidez e concentração de metais.

\section{Metodologia}

\section{Obtenção de matéria-prima}

As amostras de filmes provenientes de coleta comum foram obtidas durante uma caracterização dos resíduos sólidos realizada no Aterro Sanitário de Indaiatuba-SP. Nesta caracterização, o lixo da cidade foi dividido em 27 itens, sendo três deles filmes de HDPE, LDPE e PP. Outros filmes receberam classificação distinta, como os de outros polímeros ou metalizados ${ }^{[6]}$. Nas 3 últimas medidas de caracterização em aterro, de um total de 10 realizadas ao longo de um ano, separou-se as amostras para o estudo sobre a lavagem de filmes aqui apresentado.

A separação dos filmes de HDPE, LDPE e PP foi semelhante à realizada em cooperativas de reciclagem, sucateiros e recicladoras. Esta se baseia em propriedades simples que diferenciam estes filmes, como transparência, som ao amassar, chama, identificação de símbolos etc ${ }^{[6-8]}$.

Uma vez considerados um dos três filmes de interesse, os que apresentassem som estridente quando amassados foram classificados como PP. São normalmente feitos com polipropileno invólucros de cigarros e de CDs, embalagens de macarrão, biscoitos etc. É possível que embalagens opacas ou translúcidas de HDPE tenham sido colocadas como
PP e vice-versa. Filmes de HDPE também apresentam som estridente ao amassar, geralmente menos pronunciado que o $\mathrm{PP}^{[6-8]}$.

Os filmes identificados como de polietileno foram divididos basicamente em opacos/translúcidos vs. transparentes: os opacos e translúcidos (como as sacolas de super-mercado, sacos de lixo etc), foram classificados como HDPE enquanto os transparentes (como sacos de arroz e feijão) em LDPE. É bastante provável, entretanto, que com o HDPE tenha sido colocado, por exemplo, filmes de LDPE tingidos ou blendas de HDPE e LDPE, inclusive recicladas. Também é razoável supor que nos filmes considerados como LDPE tenham sido colocados também filmes feitos de polietileno de baixa densidade linear (LLDPE ou PEBDL) ou de blendas de LDPE/ LLDPE $^{[6-8]}$.

Embora a separação realizada não seja perfeita é considerada suficiente para a reciclagem de polietilenos e de PP, visando a obtenção de produtos com propriedades razoáveis, principalmente com relação a opacidade, translucidez ou transparência. A separação mais criteriosa envolveria testes geralmente mais caros e demorados, tornando sua aplicação não compensatória para o ganho de propriedade (e de valor agregado, quando fosse o caso) possível.

Os filmes de PP, HDPE e LDPE de coleta seletiva também foram divididos conforme a separação explicada para a matéria-prima de aterro. Neste caso, três amostras foram utilizadas para a pesquisa, duas obtidas em comércios de sucatas da cidade de Sorocaba (que comercializam uma série de materiais, inclusive plásticos) e a outra no sistema de coleta seletiva da UNESP-Sorocaba. Invariavelmente a disponibilidade de filmes das amostras tanto de coleta comum quanto de coleta seletiva era muito maior que o necessário (estabelecido como $150 \mathrm{~g}$ por amostra), o que motivou a realização da amostragem conforme a NBR 10007 (quarteamento) ${ }^{[5,9]}$.

\section{Lavagem e caracterização da água residuária}

Procedeu-se a lavagem em laboratório das amostras de filmes plásticos em condições adaptadas de estudo anterior sobre otimização de lavagens de filmes pós-consumo de polietilenos ${ }^{[10]}$. Essa lavagem não é a comumente empregada em indústrias (que utiliza normalmente somente água e muita agitação), mas foi a escolhida para o estudo pois desejava-se a melhor limpeza possível dos filmes, fundamental para a obtenção da quantidade máxima de impurezas presentes.

Para cada uma das seis lavagens (filmes de PP, HDPE e LDPE de coleta seletiva e comum), foram utilizadas amostras de $0,150 \mathrm{~kg}$ de filme, que foram picotadas com tesoura, colocadas em um tanque contendo $15 \mathrm{~L}$ de água previamente aquecida a $50{ }^{\circ} \mathrm{C}$ e com $3 \%$ em massa de agente de limpeza (no caso, o hidróxido de sódio - $\mathrm{NaOH}$ ). Posteriormente, procedeu-se a agitação da mistura durante 3 minutos, seguida do enxágüe individual de cada tira de filme e secagem total ao ar por três dias e em estufa a $50{ }^{\circ} \mathrm{C}$ por 24 horas, para posterior pesagem e comparação com a massa obtida anteriormente à lavagem. A caracterização da água de lavagem 
foi realizada segundo sua turbidez, teor de sólidos totais e teor de sólidos sedimentáveis, todos em duplicata ${ }^{[11]}$.

Para obter o teor de sólidos totais mediu-se a quantidade de material sólido presente numa amostra de água $(5 \mathrm{~mL})$ dentro de um cadinho que ficou em estufa Fanem Modelo 320-SE a $95^{\circ} \mathrm{C}$ até a secagem (constatada visualmente), o que durou cerca de 4 horas. Posteriormente, a temperatura da estufa foi elevada para $120^{\circ} \mathrm{C}$, patamar em que o cadinho permaneceu por mais 2 horas $^{[11]}$.

O teor de sólidos sedimentáveis foi obtido ao verter $1 \mathrm{~L}$ de amostra num cone fechado e graduado, chamado Cone de Imhoff. Após 45 minutos de espera, a água foi levemente agitada com bastão de vidro e esperou-se mais 15 minutos para a leitura da quantidade de sólidos que sedimentou durante o ensaio $^{[11]}$. Esta medida trata-se de um importante parâmetro, uma vez que uma das formas mais baratas e utilizadas para tratamento de efluentes é a decantação, normalmente dimensionada a partir do teor de sólidos sedimentáveis.

A turbidez foi obtida no espectrofotômetro Hach DR/2000 com $25 \mathrm{~mL}$ de alíquota a temperatura ambiente a partir da relação entre a intensidade da luz incidente na amostra (comprimento de onda de $450 \mathrm{~nm}$ ) e a da luz captada na mesma direção após a passagem pela amostra, dando um indicativo quantitativo de impurezas capazes de absorver e/ou desviar a luz de sua trajetória inicial.

\section{Determinação do teor de metais na água de lavagem}

A determinação do teor de cobre, cádmio, ferro, manganês, cromo, chumbo, níquel, alumínio e zinco (escolhidos por serem considerados os poluentes mais comuns de serem encontrados em corpos d'água) foi feita, em duplicata, por espectrometria de absorção atômica. A quantidade de álcali fez com que o pH mínimo medido (pHmetro Hanna Instruments HI 98107) para a solução de lavagem, à $50{ }^{\circ} \mathrm{C}$, fosse de 12, o que tenderia a facilitar a precipitação dos metais. Por esta razão, realizou-se uma nova lavagem, porém somente com água desionizada, mantendo aproximadamente a mesma relação utilizada na lavagem com hidróxido de sódio: $10 \mathrm{~g}$ de plásticos lavados em $880 \mathrm{~mL}$ de água desionizada, a $50{ }^{\circ} \mathrm{C}$ por 3 minutos. Assim como no caso dos ensaios com água de lavagem alcalina, as amostras de água de lavagem sem hidróxido de sódio foram coletadas com o meio em constante agitação, para dificultar precipitações.

Ao final da lavagem, $200 \mathrm{~mL}$ de amostra foram retirados e concentrados até $100 \mathrm{~mL}$ mediante aquecimento a $120^{\circ} \mathrm{C} \mathrm{em}$ béquer parcialmente coberto. Acrescentou-se então $50 \mathrm{~mL}$ de ácido nítrico e promoveu-se a digestão ácida da matéria orgânica ao aquecer (novamente em béquer coberto) a cerca de $120{ }^{\circ} \mathrm{C}$ a solução até o volume final de $60 \mathrm{~mL}$. Transferiuse quantitativamente o obtido até um balão volumétrico de $100 \mathrm{~mL}$ e completou-se o volume com água desionizada ${ }^{[12]}$.

Os teores de metais das amostras após a digestão foram determinados por espectrometria de absorção atômica (FS-240 Varian), utilizando-se solução padrão multielementar de metais para preparação da curva de calibração ${ }^{[12]}$.

\section{Resultados e Discussão}

As Tabelas 1 e 2 apresentam os resultados do percentual real de filmes plásticos, após a retirada de impurezas (sólidas ou líquidas) por meio de lavagem, enxágüe e secagem, em amostras de coleta comum e de coleta seletiva, respectivamente.

Segundo a Tabela 1, na reciclagem de filmes plásticos provenientes de coleta comum, anteriormente ao reprocessamento, é necessário que uma recicladora tenha que retirar dos filmes por meio da lavagem, como impurezas, cerca de $40 \%$ da massa atribuída aos polietilenos e cerca de $30 \%$ da massa atribuída ao polipropileno. Ou seja, de cada tonelada de filmes de polietilenos provenientes de coleta comum, cerca de $400 \mathrm{~kg}$ são impurezas, líquidas e sólidas, que serão transferidas à água durante a lavagem, necessária à reciclagem. Para filmes de polipropileno, esse montante é menor, porém ainda bastante alto: cerca de $30 \%$ (300 kg de impurezas por tonelada).

Já quando a análise é feita a partir dos resultados da Tabela 2, ou seja, quando ocorre a separação na fonte geradora de resíduo e a coleta seletiva, a massa de materiais estranhos aos polímeros que deve ser retirada é, em média, de 5 a $10 \%$. Ou seja, a simples opção pela reciclagem de filmes de coleta seletiva significa cerca de $20 \%$ menos impurezas a serem separadas pela lavagem e posteriormente tratadas, ou seja, $200 \mathrm{~kg}$ de material polimérico a mais por tonelada.

Quando os resultados da Tabela 2 são avaliados relativamente às amostras obtidas em comércio de sucatas, tem-se índice de até $16 \%$ de impurezas (PP). Em que pese a grande diminuição no teor de impurezas em relação à coleta comum (Tabela 1), este índice pode ser considerado alto, principalmente ao se comparar ao teor de impurezas obtido em sistema de coleta seletiva de universidade (máximo de 4,7\% - HDPE). Essa diferença se dá em virtude do relativo desprezo com que o material é tratado em estabelecimentos que comercializam resíduos para a reciclagem (devido ao seu baixo preço comparativamente aos outros recicláveis comercializados), tendo acondicionamento bastante falho, normalmente ao ar livre e expostos ao sol, chuva e à poeira, o que facilita a impregnação de impurezas.

Apesar dos resultados mostrados nas Tabelas 1 e 2, a reciclagem de filmes plásticos com tais índices de impurezas ainda é considerada viável, embora transfira para a água a porção indesejável do negócio, tornando-o menos lucrativo devido ao tratamento do efluente. Aos impactos ambientais e econômicos da lavagem, somam-se os decorrentes do transporte de uma grande quantidade de massa sem qualquer utilidade para os compradores da matéria-prima, que pagam menos em relação a resíduos advindos de coleta seletiva: segundo o compromisso empresarial para a reciclagem (CEMPRE), o preço médio do quilo de plástico filme prensado limpo na cidade de São Paulo em dezembro de 2007 era cerca de 70\% superior ao preço do filme somente prensado e considerado sujo ${ }^{[13]}$.

Observa-se ainda pela Tabela 1 que, quando provenientes de coleta comum, os filmes de PP forneceram índices de impurezas menores quando comparados aos polietilenos. 
Tabela 1. Teor de filmes plásticos de amostragens de coleta comum após lavagem, enxágüe e secagem.

\begin{tabular}{cccccr}
\hline \multicolumn{7}{c}{ Plásticos (\%) } \\
\hline Filme plástico & Amostragem 1 & Amostragem 2 & Amostragem 3 & Média (\%) & Desvio-padrão (\%) \\
\hline HDPE & 82,1 & 51,1 & 45,9 & 59,7 & 19,6 \\
LDPE & 62,6 & 49,3 & 63,8 & 58,6 & 8,0 \\
PP & 49,3 & 70,1 & 91,8 & 70,4 & 21,3 \\
\hline
\end{tabular}

Tabela 2. Teor de filmes plásticos de amostragens de coleta seletiva após lavagem, enxágüe e secagem.

\begin{tabular}{ccccc}
\hline \multicolumn{5}{c}{ Plásticos $(\%)$} \\
$\begin{array}{c}\text { Filme } \\
\text { plástico }\end{array}$ & $\begin{array}{c}\text { Comércio } \\
\text { de sucatas } \\
(\%)\end{array}$ & $\begin{array}{c}\text { Coleta seletiva da } \\
\text { UNESP-Sorocaba } \\
(\%)\end{array}$ & $\begin{array}{c}\text { Média } \\
(\%)\end{array}$ & $\begin{array}{c}\text { Desvio- } \\
\text { padrão } \\
(\%)\end{array}$ \\
\hline HDPE & 84,0 & 95,3 & 89,6 & 8,0 \\
LDPE & 93,8 & 97,7 & 95,7 & 2,7 \\
PP & 84,5 & 96,2 & 90,4 & 8,3 \\
\hline
\end{tabular}

Este comportamento provavelmente tem explicação no fato de que boa parte dos filmes de polietilenos é utilizada como embalagens de produtos úmidos (como frios, verduras etc) e como invólucro final do lixo das residências, com a função de evitar que os líquidos presentes se espalhem. Já os filmes de polipropileno são normalmente utilizados em embalagens de produtos secos, como bolachas, biscoitos, macarrão, CDs etc. Na Tabela 2, relativa à coleta seletiva, essa distinção de impregnação de impurezas não pode ser feita, uma vez que os resultados do PP são semelhantes aos do HDPE e distintos do LDPE, que apresentou um percentual médio de impurezas menor. Esse resultado provavelmente tem origem na valorização dos filmes transparentes perante os outros filmes.

As Tabelas 3 e 4 apresentam os resultados do teor de sólidos totais e sedimentáveis, bem como a turbidez da água de lavagem de filmes plásticos provenientes de coleta comum e seletiva, respectivamente.

Ao analisar as Tabelas 3 e 4 separadamente, um dos resultados que mais chama atenção é o valor relativamente alto dos desvios-padrão (geralmente menores para coleta seletiva), o que reflete a heterogeneidade das amostras.

Comparando-se as Tabelas 3 e 4, observa-se que quando proveniente de coleta seletiva, o efluente possui um teor médio de sólidos totais superior que quando é proveniente de coleta comum. Deve ser ressaltado que esta lavagem dos plásticos foi realizada com a adição de 3\% em massa (em relação à massa de água) de hidróxido de sódio. Acredita-se que este hidróxido de sódio, dissolvido, tenha contribuído de forma semelhante, para os dois tipos de coleta, com teor de sólidos totais.

Quando analisados os sólidos sedimentáveis, observase pelas Tabelas 3 e 4 que o comportamento inverte-se, ou seja, amostras de coleta comum com teores superiores aos da coleta seletiva. Isto sugere que como as águas de lavagem de filmes plásticos provenientes de coleta comum possuam menos sólidos que as de coleta seletiva, uma eventual decantação provavelmente será mais eficiente em diminuir do teor de sólidos do efluente de coleta comum do que do de coleta seletiva (a exceção do PP).
Essa maior quantidade de sólidos provenientes de sistemas de coleta seletiva pode parecer incoerente com os resultados das Tabelas 1 e 2, relativas ao real teor de plásticos após a lavagem de amostras de coleta comum e seletiva. Porém, pôde-se constatar ao preparar as amostras para a lavagem, que o sistema de coleta comum faz com que fique agregado aos filmes muito líquido, normalmente proveniente de restos de alimentos. Reitera-se que o armazenamento dos filmes em comércio de sucatas se dava sem muitos cuidados, o que fazia com que fosse visível a impregnação de terra na superfície dos sacos e sacolas.

Segundo a Tabela 4, os resultados de Sólidos Totais e de Sólidos Sedimentáveis são normalmente menores na coleta seletiva da universidade (amostra 3), onde o armazenamento se dá com mais cuidados. Como foi constatado que as amostras provenientes de coleta seletiva de quaisquer fontes estavam visualmente isentas de resíduos úmidos, pode-se considerar que as impurezas medidas são somente sólidas. Dados os índices de teor de sólidos apresentados das Tabelas 3 e 4 estarem na mesma ordem de grandeza, pode-se considerar que o sistema de coleta comum traz, agregados aos filmes, tanto os sólidos (numa proporção similar à da coleta seletiva), quanto líquidos. Isto faz com que um sistema de tratamento do efluente da lavagem de amostras de coleta comum baseado somente na diminuição do teor de sólidos possa ser insuficiente.

Os valores de turbidez estão coerentes com as discussões realizadas até aqui sobre as Tabelas 1 a 4 . Estes resultados são importantes indicativos de que os plásticos de coleta comum apresentam reciclagem mais impactante do que os filmes provenientes de coleta seletiva, como apontaram as Tabelas 1 e 2 . Isso porque a água de lavagem dos plásticos coletados seletivamente apresentou turbidez menor que de coleta comum, com um máximo de 139 UNT (para a coleta comum a maior média foi de 486 UNT).

Com relação aos filmes plásticos de coleta comum, a Tabela 3 aponta que as médias dos teores de sólidos foram inferiores para o PP em relação ao LPDE e ao HDPE. Isso já era esperado com base nos resultados da Tabela 1, pois o PP forneceu percentual de impurezas menor que os polietilenos. Para turbidez, porém, esse comportamento não se repete, o que pode ser atribuído principalmente ao resultado da amostra 2, que atingiu 617 UNT, o máximo valor obtido em todos os experimentos. Na amostragem dos filmes a serem lavados, foram obtidos vários sacos de PP com grande quantidade impregnada de sólidos e gordura, em comparação com outras amostras. 
Mancini, S. D. et al. - Reciclagem de filmes de poliolefinas pós-consumo

Tabela 3. Teor de sólidos totais e sedimentáveis, bem como a turbidez da água de lavagem das amostras de filmes plásticos provenientes de coleta comum.

\begin{tabular}{ccccc}
\hline Filme & Amostragem & Sólidos totais $\left(\mathbf{m g . \mathbf { L } ^ { - 1 } )}\right.$ & Sólidos sedimentáveis $\left(\mathbf{m L} \cdot \mathbf{L}^{-\mathbf{1}} \cdot \mathbf{h}^{\mathbf{1}}\right)$ & Turbidez $(\mathbf{U N T})$ \\
\hline HDPE & 1 & 19380 & 3,5 & 457 \\
& 2 & 28720 & 6,0 & 569 \\
& 3 & 22660 & 1,3 & 432 \\
& Média & 23586 & 3,6 & 486 \\
LDPE & D.P. & 4738 & 2,3 & 73 \\
& 1 & 23190 & 7,5 & 342 \\
& 2 & 25630 & 3,5 & 338 \\
PP & 3 & 24530 & 0,7 & 309 \\
& Média & 24450 & 3,9 & 54 \\
& D.P. & 1222 & 3,4 & 432 \\
& 1 & 19660 & 0,5 & 617 \\
& 2 & 21840 & 2,0 & 214 \\
\end{tabular}

D.P. = desvio-padrão.

Tabela 4. Teor de sólidos totais e sedimentáveis, bem como da turbidez da água de lavagem das amostras de filmes plásticos provenientes de coleta seletiva.

\begin{tabular}{|c|c|c|c|c|}
\hline Filme & Amostragem & Sólidos totais (mg.L $\mathbf{L}^{-1}$ ) & Sólidos sedimentáveis $\left(\mathrm{mL} \cdot \mathrm{L}^{-1} \cdot \mathrm{h}^{-1}\right)$ & Turbidez (UNT) \\
\hline \multirow[t]{5}{*}{ HDPE } & 1 & 47320 & 4,0 & 125 \\
\hline & 2 & 28520 & 2,5 & 82 \\
\hline & 3 & 27850 & 0,7 & 53 \\
\hline & Média & 34563 & 2,4 & 87 \\
\hline & D.P. & 11053 & 1,7 & 36 \\
\hline \multirow[t]{5}{*}{ LDPE } & 1 & 37590 & 1,7 & 154 \\
\hline & 2 & 15770 & 2,9 & 104 \\
\hline & 3 & 26780 & 0,6 & 31 \\
\hline & Média & 26713 & 1,8 & 96 \\
\hline & D.P. & 10910 & 1,2 & 62 \\
\hline \multirow[t]{5}{*}{ PP } & 1 & 31920 & 3,0 & 170 \\
\hline & 2 & 39700 & 2,4 & 130 \\
\hline & 3 & 24570 & 3,0 & 118 \\
\hline & Média & 32063 & 2,8 & 139 \\
\hline & D.P. & 7566 & 0,3 & 27 \\
\hline
\end{tabular}

D.P. $=$ desvio-padrão.

A Tabela 5 apresenta os teores cobre, manganês, ferro, níquel, cromo, chumbo, alumínio, zinco e cádmio encontrados nos efluentes da lavagem de filmes plásticos provenientes de coleta comum e seletiva. Além destes resultados são apresentados na Tabela 5 as quantidades máximas aceitáveis para cada um desses metais em corpos d'água doce classe 3 no Brasil, bem como os limites máximos aceitáveis de lançamento de efluentes em quaisquer corpos d'água. Esses valores são estabelecidos pela Resolução número 357 de 2005 do Conselho Nacional do Meio Ambiente (CONAMA) e, segundo esta legislação, corpos d'água que possuírem parâmetros que ultrapassem os estabelecidos para corpos d'água classe 3 são considerados classe 4. Estes últimos são rios, lagos ou lagoas tão poluídos que são proibidos de serem utilizados como fonte de água potável para a população, mesmo após o emprego de técnicas avançadas de tratamento ${ }^{[14]}$.
Num corpo d'água classe 3 é admitido despejo de efluentes, desde que após tratamento prévio e se a vazão do efluente e a conseqüente adição de poluentes em relação às condições naturais do corpo d'água não degradá-lo a ponto de tornar seus parâmetros semelhantes aos de classe 4 . A resolução lista, para a classificação de corpos d'água, 102 valores máximos de propriedades como coliformes, demanda bioquímica de oxigênio, turbidez e pH, além de parâmetros orgânicos e inorgânicos. Para lançamento de efluentes são 31 valores máximos, como sólidos sedimentáveis, $\mathrm{pH}$, temperatura e vários compostos orgânicos e inorgânicos. Além da importância com relação a tratamento e contaminação, uma das razões da escolha dos nove metais foi que constavam das duas listas da resolução 357/2005 (a exceção do alumínio) ${ }^{[14]}$.

Observa-se pela Tabela 5 que o teor de metais das águas de lavagem, seja de coleta comum ou seletiva, está dentro 
Tabela 5. Comparação entre as concentrações de cobre, manganês, ferro, níquel, cádmio, cromo, chumbo, zinco e alumínio presentes nas águas de lavagem dos filmes plásticos provenientes de coleta seletiva e comum, e os valores orientadores estabelecidos pela Resolução CONAMA 357/2005 para corpos d'água e lançamento de efluentes ${ }^{[14]}$.

\begin{tabular}{crrrrrrrr}
\hline $\begin{array}{c}\text { Metal } \\
\left(\mu \text { g.L } \mathbf{~}^{-1}\right)\end{array}$ & \multicolumn{3}{c}{ Coleta seletiva } & \multicolumn{3}{c}{ Coleta comum } & $\begin{array}{c}\text { Valores máximos } \\
\text { permitidos para corpos } \\
\text { d'água classe 3 }\end{array}$ & $\begin{array}{c}\text { Valores máximos } \\
\text { permitidos para } \\
\text { lançamento de efluentes }\end{array}$ \\
\cline { 2 - 7 } $\mathrm{Cu}$ & 21,00 & 27,75 & 11,25 & 324,50 & 9,25 & 6,75 & 13,00 & $1.000,00$ \\
$\mathrm{Mn}$ & 21,50 & 30,50 & 16,50 & 38,75 & 26,25 & 18,75 & 500,00 & $1.000,00$ \\
$\mathrm{Fe}$ & 260,75 & 685,25 & 188,75 & 297,50 & 180,00 & 330,5 & $5.000,00$ & $15.000,00$ \\
$\mathrm{Ni}$ & 118,25 & 100,75 & 133,50 & 112,75 & 78,50 & 99,5 & 25,00 & $2.000,00$ \\
$\mathrm{Cd}$ & 30,75 & 23,25 & 34,50 & 28,25 & 17,75 & 24,5 & 10,00 & 200,00 \\
$\mathrm{Cr}$ & 0,00 & 0,00 & 0,00 & 0,00 & 0,00 & 0,00 & 50,00 & 500,00 \\
$\mathrm{~Pb}$ & 56,75 & 39,75 & 51,00 & 55,50 & 70,25 & 62,00 & 33,00 & 500,00 \\
$\mathrm{Zn}$ & 5,50 & 12,00 & 6,75 & 42,25 & 17,50 & 9,00 & $5.000,00$ & $5.000,00$ \\
$\mathrm{Al}$ & 86,75 & 166,75 & 91,00 & 93,00 & 71,50 & 146,50 & 200,00 & n.d. \\
\hline
\end{tabular}

n.d. = não determinado pela legislação.

dos padrões determinados para lançamento de efluentes. Se forem consideradas vazões do corpo d'água e do efluente não tratado idênticas, o despejo do efluente não causaria ultrapassagem dos teores de manganês, cromo, zinco, ferro e alumínio, conforme se verifica pela Tabela 5. Em relação a níquel, cádmio e chumbo os teores estão proibitivos para quaisquer efluentes de lavagem comparativamente ao máximo estabelecido para corpos d'água classe 3. Em termos de cobre, a água da lavagem de polipropileno de qualquer coleta e a de polietileno alta densidade de coleta seletiva também transformariam o rio, lago ou lagoa em fonte de água proibida para abastecimento humano. Como os teores de cobre, níquel, cádmio e chumbo não são tão superiores aos máximos admissíveis para corpos d'água classe 3 , acredita-se que um tratamento simples de diluição desse efluente no corpo d'água pode ser suficiente para torná-lo apto com relação ao teor desses metais. Isso, somente caso a vazão do rio onde será realizado o despejo for superior à do efluente (o que é relativamente comum). Caso contrário, tratamentos mais complexos se fazem necessários. Esta diluição poderia auxiliar ainda na diminuição do impacto dos líquidos arrastados dos filmes durante a lavagem de amostras de coleta comum.

Uma análise da Tabela 5 com relação a todos os teores de metais determinados representa uma preocupação para a reciclagem de filmes plásticos, ainda mais porque somente para o zinco a coleta seletiva apresentou melhores índices com relação à coleta comum. No caso do níquel e cádmio ocorreu comportamento justamente inverso.

Os metais presentes na água de lavagem provavelmente foram arrastados da superfície do filme e ali estavam devido a acondicionamento anterior (por exemplo, de uma bateria de $\mathrm{Ni}-\mathrm{Cd}$ ) ou à presença de tintas de impressão ${ }^{[15]}$. Estas, dependendo da cor, podem conter uma série de óxidos ou hidróxidos metálicos, como os de ferro (normalmente utilizados para pigmentos marrom ou vermelho), níquel (verde ou amarelo), cádmio (amarelo, vermelho e laranja), chumbo (amarelo, vermelho e verde), zinco (verde) e alumínio (azul ${ }^{[16]}$. Embora haja uma tendência, por pressões ambientais, de substituição de pigmentos inorgânicos (em especial os de chumbo) por orgânicos, compostos metálicos ainda são bastante utilizados pela indústria de concentrados de cor.

Voltando às Tabelas 3 e 4, em termos de turbidez a resolução estabelece o valor máximo de 100 UNT para corpos d'água classe 3, o que faz com que somente os efluentes de lavagem de filmes de coleta seletiva atendam o estabelecido, à exclusão do PP. Para lançamento de efluentes não são estabelecidos valores de turbidez, porém o são de temperatura e sólidos sedimentáveis ${ }^{[14]}$.

A temperatura máxima admitida é de $40{ }^{\circ} \mathrm{C}$, abaixo da temperatura de lavagem $\left(50^{\circ} \mathrm{C}\right)$. Há ainda restrição com relação a um aumento máximo de $3{ }^{\circ} \mathrm{C}$ na zona de mistura (região do corpo d'água onde ocorre o despejo e a diluição inicial do efluente), o que obviamente depende da vazão e condições anteriores do corpo receptor. Dessa maneira, a mesma diluição proposta para a melhora no nível de alguns metais poderia ser suficiente para que os $40{ }^{\circ} \mathrm{C}$ não fossem ultrapassados, novamente somente se o efluente apresentar vazão inferior ao rio onde ocorrerá o despejo ${ }^{[14]}$.

Para sólidos sedimentáveis, a resolução 357/2005 estabelece valores máximos de $1 \mathrm{~mL} \cdot \mathrm{L}^{-1} \cdot \mathrm{h}^{-1}$. Os teores obtidos após a lavagem de filmes plásticos reprovariam praticamente todos os efluentes (exceção do PP de coleta comum), independente da forma de coleta do filme plástico (Tabelas 3 e 4). Dessa maneira, recomenda-se um tratamento de decantação para o efluente de lavagem de filmes plásticos, tão longo quanto o necessário ou acelerado por agentes coagulantes/floculantes.

Junto com a diminuição dos teores de sólidos totais e sedimentáveis do efluente, a decantação melhoraria ainda a turbidez e contribuiria para a diminuição da temperatura do efluente bem como poderia ocorrer a precipitação de pelo menos parte dos metais. Desta maneira, uma decantação bem dimensionada pode eliminar a diluição anteriormente proposta e tornar o despejo do efluente viável em quaisquer corpos d'água, independente da vazão. Porém, deverá haver uma retirada periódica do lodo gerado na decantação, sua classificação quanto à periculosidade e posterior tratamento e/ou disposição final adequados. 
Dessa maneira, tornar o efluente apto ao despejo conforme determina a legislação é um procedimento relativamente barato e que deve ser fiscalizado pelo poder público, para que se evite a prática corriqueira de se despejar a água de lavagem sem condições de reutilização direta ou indiretamente nos corpos d'água. Esse comportamento de alguns recicladores é certamente negativo para a indústria da reciclagem de plásticos, que tem mercado graças, em parte, ao apelo ecológico.

Deve ser ressaltado que este estudo reporta resultados de 14 parâmetros (turbidez, $\mathrm{pH}$, sólidos totais, sólidos sedimentáveis, temperatura e de nove metais) enquanto a resolução CONAMA 357/2005 lista 31 parâmetros sobre lançamento de efluentes e 102 sobre classificação de corpos d'água. Ou seja, para a definição do tratamento a ser implantado por uma recicladora, outros ensaios de caracterização dos efluentes e de tratabilidade dos mesmos podem ser exigidos por órgãos ambientais que licenciam e fiscalizam empreendimentos desta natureza. Um desses ensaios, em especial para a água de lavagem de resíduos de coleta comum (em virtude da notável impregnação de líquidos de restos de alimentos), provavelmente seria a determinação da carga orgânica do efluente (normalmente a partir da demanda bioquímica de oxigênio). Dependendo de seus resultados pode haver a necessidade de implantação de um sistema de tratamento aeróbio ou anaeróbio, bem mais caros que uma simples decantação/diluição, o que é mais um aspecto favorável à utilização de matéria-prima de coleta seletiva, virtualmente sem líquidos impregnados.

No mesmo artigo em que apresentaram a otimização da lavagem de polietilenos provenientes de coleta comum, Remédio, Zanin e Texeira mediram as propriedades apresentadas na Tabela 3, obtendo os seguintes resultados: 5,190 mg. $\mathrm{L}^{-1}$ de sólidos totais, $14 \mathrm{~mL} \cdot \mathrm{L}^{-1} \cdot \mathrm{h}^{-1}$ de sólidos sedimentáveis e turbidez de $576 \mathrm{UNT}^{[10]}$. Se faz interessante também uma comparação dos parâmetros encontrados para o efluentes de lavagem de filmes plásticos com o reportado por Santos et al. para resíduos rígidos de HDPE e PP misturados. As amostras, também pós-consumo de coleta comum, foram obtidas no mesmo local em que Remédio, Zanin e Teixeira coletaram os filmes, uma usina de triagem. O sistema de lavagem utilizado por Santos et al. foi diferente do empregado neste estudo (envolveu pré-lavagem somente com água e posterior lavagem à temperatura ambiente com $0,5 \%$ de hidróxido de sódio). Alguns dos resultados apontados pelos autores foram, somando-se os da pré-lavagem e da lavagem, 8,800 mg. $\mathrm{L}^{-1}$ de sólidos totais, $45 \mathrm{~mL} \cdot \mathrm{L}^{-1} \cdot \mathrm{h}^{-1}$ de sólidos sedimentáveis, 267 UNT e 1,110 $\mu \mathrm{g} . \mathrm{L}^{-1}$ de $\mathrm{Pb}, 50 \mu \mathrm{g} . \mathrm{L}^{-1}$ de cádmio, $70 \mu \mathrm{g} . \mathrm{L}^{-1}$ de $\mathrm{Mn}$ e 4,370 $\mu \mathrm{g} . \mathrm{L}^{-1}$ de $\mathrm{Fe}^{[15]}$. Em linhas gerais, os efluentes apresentados neste estudo a partir de matérias-primas de aterro tiveram quantidades maiores de sólidos totais e menores de sólidos sedimentáveis, enquanto os de turbidez podem ser considerados semelhantes aos apresentados pelos dois grupos de autores ${ }^{[10,15]}$. No caso dos metais, os resultados de Santos et al. são superiores, principalmente para o chumbo e ferro. Além de partirem de matéria-prima completamente diferentes (plásticos rígidos), ao contrário do caso dos filmes de aterro para o ensaio de determinação de metais, os autores realizaram lavagem com hidróxido de sódio, agente que destacaram como facilitador da retirada de metais $^{[15]}$.

Todos esses resultados ressaltam que a lavagem de plásticos apresenta impactos ambientais significativos e que são necessários esforços para se melhorar a qualidade da matéria-prima e se estabelecer tratamentos eficientes dos efluentes gerados.

\section{Conclusões}

A separação de filmes plásticos de resíduos sólidos urbanos foi realizada conforme se faz normalmente em cooperativas e indústrias, baseada em propriedades simples que, se não a fazem perfeita do ponto de vista de exatidão do tipo de polímero, são suficientes para garantir propriedades finais do reciclado satisfatórias. A retirada de impurezas líquidas e sólidas de amostras de filmes de HDPE, LDPE e PP, por meio de um sistema de lavagem otimizado em estudos de outros autores, permitiu constatar que, no mínimo, $30 \%$ da massa atribuída aos filmes plásticos é constituída de impurezas quando a fonte da matéria-prima é a coleta comum. Quando se trata de coleta seletiva, o teor máximo de impurezas obtido é pouco maior que $10 \%$. Nas amostras de coleta comum, os filmes de polipropileno mostraram-se menos impregnados que os de polietilenos.

Essas diferenças refletiram-se também na turbidez e sólidos sedimentáveis. No caso do teor de metais e sólidos totais, a coleta seletiva não apresentou melhoras na qualidade do efluente em relação à coleta comum. Mesmo assim, considerando-se principalmente a quantidade de impurezas presentes (não somente sólidas), pode-se afirmar que a coleta seletiva se mostra menos impactante em termos ambientais que a comum. Dessa maneira, filmes provenientes de coleta seletiva, fonte preferível de matéria-prima por parte de indústrias recicladoras, representam a necessidade de separação, na lavagem, de uma quantidade muito menor, cerca de $20 \%$ no mínimo, de impurezas.

Estudos sobre o tratamento dos efluentes de uma recicladora de filmes devem ser feitos caso a caso, considerandose inclusive a classe e vazão do rio que receberá o efluente tratado. No caso de um rio classe 3 com vazão superior à do efluente, os resultados obtidos neste estudo indicam que a decantação pode ser a única etapa necessária, pois poderia diminuir o teor de sólidos sedimentáveis, a temperatura, a turbidez e o teor dos metais com índices mais impactantes $(\mathrm{Ni}, \mathrm{Cd}$ e $\mathrm{Pb}$ ).

\section{Agradecimentos}

Os autores agradecem ao PIBIC/UNESP, à Pró-Reitoria de Extensão da UNESP, à FAPESP (processos 06/55213-5 e 04/08718-9), à Corpus Engenharia e Obras Ltda. (em espe- 
cial ao Eng. Wilton A. R. da Cunha) pelo acesso ao aterro em Indaiatuba bem como à Fernando Salles Rosa.

\section{Referências Bibliográficas}

1. Zanin, M. \& Mancini, S. D. - "Resíduos Plásticos e Reciclagem: Aspectos Gerais e Tecnologia", Editora da UFSCar, São Carlos - SP, (2004).

2. Wiebeck, H. \& Piva, A. M. - "Reciclagem do Plástico", Art Líber, São Paulo - SP, (2005).

3. Mano, E. B.; Pacheco, E. B. A. V. \& Bonelli, C. M. C. "Meio Ambiente, Poluição e Reciclagem". Ed. Edgard Blücher, São Paulo - SP, (2005).

4. Spinacé, M. A. S. \& De Paoli, M. A. - Quim. Nova, 28, p.65, (2005).

5. Matos, T. F. L. \& Schalch, V. - Polímeros, 17, p.346, (2007).

6. Mancini, S. D.; Nogueira, A. R.; Kagohara, D. A.; Schwartzman, J. A. S. \& Mattos, T. - Waste Manage. Res., 25, p.517, (2007).

7. Manrich, S.; Frattini, G. \& Rosalini, A. C. - "Identificação de Plásticos: uma ferramenta para reciclagem", Editora da UFSCar, São Carlos - SP, (1997).

8. Mano, E. B. \& Mendes, L. C. - "Identificação de Plásticos, Borrachas e Fibras", Ed. Edgard Blücher, São Paulo - SP, (2000).
9. ABNT - Associação Brasileira de Normas Técnicas NBR 10007: Amostragem de Resíduos Sólidos, Rio de Janeiro - RJ, (2004).

10. Remédio, M. V. P.; Zanin, M. \& Teixeira, B. A. N. - Polímeros, 9, p.177, (1999).

11. APHA - American Public Health Association - "Standard Methods for the Examination of Water and Wastewater", 20a. ed., United Book Press, Baltimore (1998).

12. Rosa, A. H.; Gouveia, D.; Bellini, I. C.; Dias Filho, N. L. \& Padilha, P. M. - Anal. Bioanal. Chem., 386, p.2153 (2006).

13. CEMPRE - Compromisso Empresarial para a Reciclagem. Disponível em: http://www.cempre.org.br/cempre_informa.php?lnk=ci_2007-1112_mercado.php. Acesso em 06 jan. 2008.

14. CONAMA - Conselho Nacional do Meio Ambiente. Resolução 357 de 17 de março de 2005. Diário Oficial [da República Federativa do Brasil], Brasília, 18 de março de 2005, seção 1, fls. 58-63.

15. Santos, A. S. F.; Manrich, S.; Agnelli, J. A. M. \& Teixeira, B. A. N. - Resour. Conserv. Recycling, 45, p.159, (2005).

16. Gächter, R.; Müller, H. \& Klemchuk, P. P. (ed.) - "Plastics Additives Handbook", $3^{\mathrm{a}}$ ed., Hanser Publishers, Munique, (1990).

Enviado: 08/02/08

Reenviado: 09/05/08

Aceito: 19/05/08 